\title{
BUILDING CONSISTENCY BETWEEN DEVELOPMENT STAGES OF NUCLEAR POWER COMPLEX AND RW MANAGEMENT SYSTEM
}

\author{
Bolshov L. A., Linge I. I. \\ Nuclear Safety Institute of RAS, Moscow, Russia \\ Article received on August 1, 2019
}

\begin{abstract}
The paper discusses interactions between operating organizations generating radioactive waste and components of the Unified State System for Radioactive Waste Management. It presents the issues requiring some coordinated decision making in the short and long run, as well as the timeframes during which these decisions are to be made and implemented.
\end{abstract}

Key words: Unified State System for Radioactive Waste Management, operating organization, borosilicate glass from SNF reprocessing, reactor graphite, very low-level waste, containers.

By the end of 2018, after vigorous studies and discussions, the main provisions of the strategy for the development of nuclear power in Russia until 2050 and for the period up to 2100 were approved [1] (hereinafter - the Strategy) This time horizon can be defined as distant future, but at the same time it can be perceived in another way - this timeframe encompasses less than two modern NPPs lifetimes. Points dealing with radioactive waste management, including spent nuclear fuel reprocessing, are presented quite concisely in the Strategy [1]. That makes sense since it specified the alternate contours for the development of the reactor fleet, while all the remaining areas - both nuclear fuel manufacturing and spent nuclear fuel and radioactive waste management, including the recycling type, will be adapted to the reactor technology as planned by the developers.

This article draws particular attention to the need of considering the interaction between the development of the Unified State System for Radioactive Waste Management (USS RW) and the evolution of nuclear technologies in the Russian nuclear power complex (NPC), including the nuclear fuel cycle and nuclear power. To account for these interactions and mutual influences, it seems of use to apply long-term planning tools that have already been used in the Russian nuclear industry. It is clear that, in terms of seeing relevant prospects, the NPC development strategy plays a crucial role.

In some cases, it seems reasonable to refer to the international experience. First of all, the one of Sweden as it demonstrates high flexibility in planning RW disposal activities related to national nuclear power performance. This is ensured by the involvement of the industry in managing disposal operator's activities. The company SKB responsible for RW disposal was established with the engagement of NPP owners. Another case in point, namely the one of the US where the Government takes the entire responsibility for a number of major tasks, including those associated with geological disposal of SNF and nuclear legacy cleanup. However, the experience of the US on the implementation of SNF 
disposal project seems being not quite successful. Commissioning of a centralized facility was hindered, which resulted in numerous lawsuits against the Government on the compensation of the costs associated with excess storage of spent nuclear fuel at NPP sites. Under the third case in point, namely the one Germany, NPP owners also demanded that the state cover the costs associated with the forced early shutdown of their NPPs, including nuclear decommissioning and RW disposal costs.

Below are considered the issues of mutual influence - these are presented separately for each of the four historical periods that can be identified in NPC background (Table 1). The recent past and the near future are intentionally separated, since the conclusions for the near future seem to be of the biggest importance. It's considered essential that we are discussing not different systems, but a single one - the nuclear power and industrial complex, involving uranium ore mining, fabrication of nuclear fuel, nuclear power production and a set of units associated with the final stages of nuclear life cycle (FSLC), involving the entire USS RW. The division resulted only from the need for mutual consideration of various components belonging to a single large effective environmentally friendly and multi-purpose system - the one that NPC should become.
Distant past. During the first sixty years of its development, the nuclear industry, and then the nuclear power evolved based on the principle suggesting the accumulation of deferred problems in radioactive waste management (Table 1 ). The RW management area was viewed as firmly secondary in comparison with the challenges associated with commissioning of new capacities and technologies at that time. Even emergencies and accidents at RW storage facilities did not affect the main production facilities. For example, the windblown release of contaminants from the lake Karachai and the resulting contamination of the adjacent territories has prompted the decision on launching relevant backfilling efforts, however, did not contribute to any formal discussions on the review of the existing technologies suggesting the use of near-surface reservoirs for LRW storage. Contamination of groundwater and surface water at RW storage sites at Beloyarsk and Novovoronezh NPPs did not prompt any feasibility studies on introducing practically unlimited storage of RW at NPPs, including untreated solid and liquid waste. Under the planned economy, financial resources of the Government could be doled out to cover all SNF and RW management costs whenever it was needed. Alterations in social and economic setting changed the situation. The ongoing accumulation of problems

\section{Table 1. Nuclear power complex and radioactive waste management system: principal stages of development}

\begin{tabular}{|c|c|c|c|}
\hline Period & Year & Development of the nuclear power complex & RW management \\
\hline \multirow{5}{*}{$\begin{array}{c}\text { Distant } \\
\text { past }\end{array}$} & $1948-1953$ & Development of nuclear weapons complex & LRW discharged of into lake Karachai \\
\hline & 1954-1963 & First NPP & Accident at LRW storage facility \\
\hline & $1964-1985$ & $\begin{array}{l}\text { Commissioning of WWER-440, AMB, RBMK, EGP, } \\
\text { RT-1, WWER-1000 }\end{array}$ & $\begin{array}{l}\text { Commissioning of LRW deep well injection facilities (LRW DF). } \\
\text { For the first time the decision on capping the water area of the } \\
\text { lake Karachai was made. LRW leaks at NNPP and BelNPP }\end{array}$ \\
\hline & 1986-1989 & $\begin{array}{l}\text { Chernobyl, power unit shutdown at Beloyarsk and } \\
\text { Novovornezh NPPs, freezing NPP construction }\end{array}$ & \\
\hline & $1990-2005$ & $\begin{array}{l}\text { Extension of WWER-1000 fleet - Balakovo and } \\
\text { Rostov NPPs }\end{array}$ & $\begin{array}{l}\text { Critical situation at the Techa Cascade of water reservoirs. Approv- } \\
\text { al of a comprehensive plan regarding PA Mayak facilities (2003) }\end{array}$ \\
\hline \multirow[b]{2}{*}{$\begin{array}{l}\text { Recent } \\
\text { past }\end{array}$} & $2006-2007$ & $\begin{array}{l}\text { Approval of Federal Targeted Program on the } \\
\text { Development... and Federal Targeted Program } \\
\text { on Nuclear and Radiation Safety }\end{array}$ & $\begin{array}{l}\text { Ratification of the Joint Convention on the Safety of Spent Nu- } \\
\text { clear Fuel Management and on the Safety of Radioactive Waste } \\
\text { Management }\end{array}$ \\
\hline & $2008-2019$ & $\begin{array}{l}\text { Commissioning of Rostov NPP, Leningrad-2 NPP, } \\
\text { Novovoronezh NPP. Commissioning of BN- } 800 \text {. } \\
\text { Formation of a business portfolio on NPP con- } \\
\text { struction in } 2008-2019 \text { abroad. } \\
\text { Approval of the Strategy for the period of up } \\
\text { to } 2100 \\
\text { Approval of the Federal Targeted Program on } \\
\text { nuclear power technologies of new generation }\end{array}$ & $\begin{array}{l}\text { Enactment of the Federal Law on Radioactive Waste Manage- } \\
\text { ment. Establishment of NO RAO and USS RW. } \\
\text { Implementation of FTP NRS and FTP NRS-2. } \\
\text { Closure of Karachai site. } \\
\text { Commissioning of a near-surface disposal facility for RW class } 3 \\
\text { and } 4 \\
\text { Adoption of a Strategy on the deep disposal facility develop- } \\
\text { ment }\end{array}$ \\
\hline $\begin{array}{l}\text { Near } \\
\text { future }\end{array}$ & $2020-2040$ & $\begin{array}{l}\text { Development of WWER and fast reactor tech- } \\
\text { nologies. Passing the "technological crossroad" } \\
\text { for BREST-300 and BN-1200 }\end{array}$ & $\begin{array}{l}\text { Development of RW disposal system covering all types of gener- } \\
\text { ated RW, nuclear legacy cleanup, decommissioning efforts imple- } \\
\text { mented under DECON option }\end{array}$ \\
\hline $\begin{array}{c}\text { Far } \\
\text { future }\end{array}$ & $2040-2100$ & \multicolumn{2}{|c|}{$\begin{array}{l}\text { Formation of nuclear power and industrial complex with two-component nuclear energy and a full cycle of SNF } \\
\text { and RW management }\end{array}$} \\
\hline
\end{tabular}


in the field of nuclear and radiation safety during the post-Soviet period [2] required some special measures to be implemented: important decisions were made, including those on the development and implementation of federal targeted programs.

Recent past. Ratification of the Joint Convention on the Safety of Spent Nuclear Fuel Management and on the Safety of Radioactive Waste Management (December 2005) and launching the Federal Targeted Program for Nuclear and Radiation Safety (2008) were the first steps in the establishment of an appropriate legal and infrastructure setting allowing to eliminate new problems in the future. These steps enabled the enactment of a basic law in this area providing for mandatory RW conditioning and waste transfer for disposal [3]. Thus, for the reasons described above the operators were not bind upon these actions until 2011. In addition, the law introduced provisions on the Unified State System for RW Management and the authority responsible for its performance, as well as on a purpose established organization - the national operator for RW disposal. Already in 2011, against the background of a positive appraisal given to the new legislative act, [4] summarized the bottlenecks associated with the deployment of the system: establishment of a competent national operator and development of a sub-statutory regulatory framework. Particular articles of the law provided for administrative incentives for the USS RW development at the first, second and third stages of its development. The first two stages were fully implemented, as these were supported by relevant action plans approved by the Government of the Russian Federation. USS RW's regulatory and organizational framework was entirely finalized, including the establishment of a national operator and a special reserve fund, efforts on the deployment of a disposal system were launched. Unfortunately, during all these stages, operators - RW generators were only minorly involved in the development of USS RW's regulatory framework and infrastructure. This independence to some extent explains the large volume of accumulated RW and, until recently not fully overcome inertness of RW generators in awakening the new requirements in the field of RW management and associated costs.

During this period, successfully implemented were some particular projects associated with the coordination of radioactive waste management efforts, focused on regional problems and individual challenging facilities. Strategic Master Plan (SMP) for the Comprehensive Dismantlement of Nuclear Submarines and Remediation of Coastal Bases was the first case in point that enabled the optimization of the funding mechanisms associated with these activities performed under global cooperation [5]. The setting required to arrange for and finance this development was set forth by the international Northern Dimension Environmental Partnership Fund. This initially provided for the fundamental nature of relevant efforts with regard to such parameters as deadlines (three years); structure of the final results, including the project management information system; quality system, including overarching review by independent companies; high presentation level of milestones and final results. On the whole, the case study of the SMP discussed above seems to be a totally positive experience but nevertheless quite limited in terms of the considered topic as virtually it does not cover the issues associated with the development of nuclear facilities.

SMP on the Techa Cascade of water reservoirs (TCR) is another development in the field of strategic planning [6], but it also provides only limited experience. Naturally, it has been focused on the issues associated with the termination of LRW discharges and construction of a nuclear power plant or other nuclear complex that would use TCR water for cooling. But these were considered as secondary in comparison with those associated with the safety of the facility containing about $3.5 \cdot 10^{8} \mathrm{~m}^{3}$ of LRW.

Indeed, a strategy for a deep disposal facility (DDF) development [7], supported by a strategic plan of research aimed at demonstrating the longterm safety of the facility [8], directly provides for relevant efforts of operating organizations on the predisposal treatment of their RW - already accumulated and generated waste. These documents developed with the engagement of the best competent experts from all over the country, allowed to identify a large number of points stated under the DDF project that required additional research and evaluation. Relevant measures including design adjustment were provided for by the indicated documents. In addition, the Strategy specified the tasks that the operators, i. e. waste generators, shall address. These include the following: to identify the characteristics of previously accumulated vitrified wastes, to upgrade the systems providing control over the existing technologies to timely identify the missing parameters. Another task stated involves the identification of generated RW pertaining to class 2 , since the approved (design) parameters of the facility provide for the possibility of emplacing some 150 thousand $\mathrm{m}^{3}$ of radioactive waste of class 2 , the origin and characteristics of which have not been identified. The Strategy sets up the measures enabling to clarify these issues. For these reasons, two documents $[7,8]$ can be unambiguously attributed to documents contributing 
to the interaction of organizations operating under different branches of nuclear industry.

Basically, in less than 10 years since the general concept of USS RW evolved, significant and positive changes have occurred [9]. Without asserting that these initial stages of USS RW development were fully completed, we will try to show that it's now the high time for a more general coordination of nuclear technologies and disposal system development stages. Whereas, matching up certain key dates for the start or completion of individual technologies' operation has become more than relevant. Notably, in most cases RW management and disposal technologies themselves give rise to these requirements. At the same time, if the initial requirements are acknowledged, these are associated with relevant environmental problems: safety of human and wildlife. Presumably, the industry will also pose requirements of two types: many particular ones related to the disposal of specific RW types, and a comprehensive one concerning the disposal system performance, i. e. on the structure of the system, supporting infrastructure and, most importantly, on the cost and promptness of RW disposal.

The essence of the key problem associated with the current situation can be explained as follows: the regulatory documents are based on criteria allowing to categorize waste as radioactive waste, criteria for radioactive waste categorization as nonretrievable RW and the classification criteria for RW disposal approved by relevant Government Resolution of the Russian Federation in 2012. The former two are considered quite briefly here. The important point to note in their regard is that the first one contains an infinitely long list of radionuclides, including those not related to RW, and do not take into account the specific aspects of managing naturally occurring radionuclides. Whereas, the second one associated with RW categorization as non-retrievable waste, in addition to safety-based components also provides additional administrative restrictions on the origin and location of the waste.
This fraught with tremendous increase in the costs needed to address the accumulated problems. The criteria set for RW classification for disposal purposes are considered fundamental to the waste management since they affect the engineering solutions ensuring RW disposal safety. Radionuclide activities with regard for their half-lives were taken as the main criterion due to which any high activity waste is categorized as RW class 2 requiring extremely costly disposal in deep geological formations and is fundamentally incorrect for short-lived radioactive waste with a period of potential hazard of up to 500 years. Another major disadvantage associated with these criteria is the lack of a separate class for very low-level RW and, therefore, no approved tariffs for its disposal. This results in a high cost of very low-level RW disposal. It may appear that (Figure 1) after a very short time period (50-100 years) individual packages cease to be considered as radioactive waste, and the paid tariff is based on the design of the facility ensuring safety for a many-fold longer period. The situation is complicated by already established practice for RW class 3 and 4 near-surface disposal facility design development and construction providing for the same design solutions for both categories of waste.

These circumstances have been repeatedly discussed $[10,11]$ and, of course, considered as temporary in their nature. The plan for the Implementation of State Policy Fundamentals in the Field of Nuclear and Radiation Safety is seen as a positive sign upon this path indicating fast resolution of these problems. This plan suggests that by 2020 amendments are to be introduced to relevant Government Resolution of the Russian Federation.

Near future. Given the discussion provided above and further discussed issues associated with distant future, it seems fair to state that in the coming decades the efficiency and consistency of the USS RW development with the one of NPC will determine the acceptability of nuclear power on the whole, including export potential in this area. It should be
Class $4-541.2 \mathrm{~m}^{3}$ (2016)
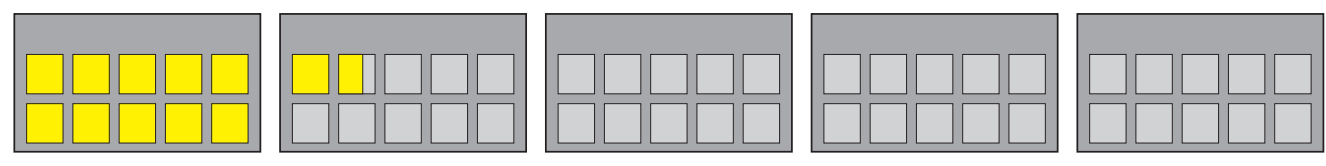

Class $3-1,908.5 \mathrm{~m}^{3}$
$(2016)$

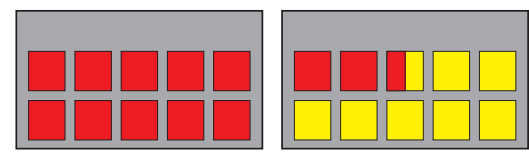

Present time 30 years

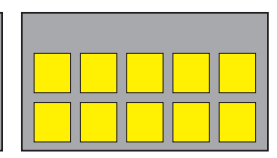

$150 \ldots 300$ years

- Class 4
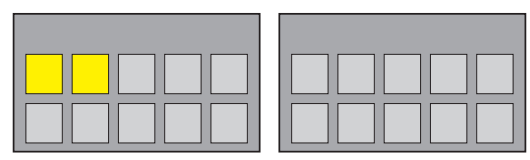

350 years

$<400$ years

— Non recognized as RW

Figure 1. RW behavior in a near-surface disposal facility 
noted that until recently, the amount of RW generated at Russian-designed nuclear power plants, as well as relevant optimization challenges, were not literally covered in literature sources. Although the first publications on this subject $[12,13]$ and open data presented in the reports of Rosenergoatom Concern can be viewed as some kind of prerequisites for such an analysis.

The transfer of radioactive waste for disposal is viewed as an essential issue governing the interaction between the USS RW and nuclear enterprises. The effectiveness of such transfer depends on the structure and location of the disposal facilities, the applicable packaging and means of transportation, and the procedures for monitoring the compliance of the transferred packages with the acceptance criteria. RW control is associated with some expenses, but the costs should be determined at the subsequent stages after relevant disposal system is established. The accumulated experience, applied during USS RW development, including the implemented activities at priority disposal facilities, allowed to form the basis for a longer-term and balanced planning of its development. However, it also demonstrated the severity of the key decision - the siting one. At the same time, most likely the situation will improve due to the growth of environmental awareness of the society. Inevitable crisis recovery in the field of production and consumption waste disposal may appear to be one of the incentives driving the progress. Under such recovery many conflicts arising during the siting of the disposal facilities should be resolved for all waste types. At the same time, relevant requirements on the volumes, classes and location of the disposal facilities should be set forth by nuclear operators. The primary inventory taking campaign has revealed that almost $530,000 \mathrm{~m}^{3}$ of retrievable SRW and $170,000 \mathrm{~m}^{3}$ of retrievable LRW has been accumulated to date. These estimates cannot be deemed as realistic in particular given the RW resulting from nuclear decommissioning.

Issues associated with building coherence between USS RW development stages and local, but major tasks, assuming that later, their practical solution will allow us to move on to general issues associated with the coordination of the disposal system's parameters and those of NPC development, firstly, and solving the accumulated problems, secondly.

The list of development stages requiring the coherence building was compiled based on the following order of the points considered: background information, the source and nature of the requirements, the addressee of the requirements within the NPC or within its component responsible for the USS RW development, a reference to the description of the situation or its disclosure, the nature of the first decision required and relevant deadlines, possible costs to be covered if the decision is not made. The first six characteristics will be presented in tables, and the costs and other comments will be discussed in a textual form. If necessary, other comments are to be provided as well. Let's first consider a situation the substantial part of which has already been partially described above.

Heat release from vitrified RW (Table 2). Until recently, a single technology was applied in Russia to vitrify the waste resulting from SNF reprocessing at FSUE PA Mayak. The specific activity of the glass produced from such vitrification generally allowed to dispose of the waste in accordance with internationally accepted criteria set for HLW heat output $\left(1 \mathrm{~kW} / \mathrm{m}^{3}\right)$ after some pre-disposal cooling of the waste or without it. In the coming years, it is planned to commission vitrification plants as part of the SNF pilot demonstration reprocessing center (PDC) providing for significantly higher activity indicators for the produced glass and its heat release. The latter raises a question on how the SNF will be processed: on a first in, first out basis or in a prearranged manner, as suggested in [14].

If a decision is not made, an unstructured stream of vitrified RW may be formed, part of which will be already excessively cooled by the time of its emplacement into the deep disposal facility, and part will require extra-long storage periods. In terms of SNF generation and at-reactor reprocessing, similar but somewhat different is the case of the pilotdemonstration power complex (PDPC) BREST-300 commissioning implemented under the Breakthrough (Proryv) project. A new radioactive waste stream will be generated in this case, which, even given its fractionation at the first stages, shall be subject to geological disposal [15].

Table 2. Main characteristics of the challenging situation regarding the restrictions imposed on the heat output of vitrified $R W$ resulting from SNF reprocessing (class 1)

\begin{tabular}{|l|c|c|c|c|}
\hline $\begin{array}{c}\text { Background/origin } \\
\text { of the requirements }\end{array}$ & $\begin{array}{c}\text { Nature of the } \\
\text { requirements }\end{array}$ & $\begin{array}{c}\text { Addressee of the re- } \\
\text { quirements }\end{array}$ & \multicolumn{1}{c|}{ Required solution } & Deadline \\
\hline Acceptance criteria & $\begin{array}{l}\text { Maximum allow- } \\
\text { able heat output }\end{array}$ & $\begin{array}{l}\text { Vitrification facilities } \\
\text { of the PDC for SNF } \\
\text { reprocessing at MCC }\end{array}$ & $\begin{array}{l}\text { Setting up the starting date for this type of } \\
\text { RW disposal, i.e. prearranged selection of SNF of the vitrification } \\
\text { to form the batches transferred for disposal }\end{array}$ & $\begin{array}{l}2020 \text { (commissioning } \\
\text { facility) }\end{array}$ \\
\hline
\end{tabular}


Table 3. Main characteristics of the challenges associated with graphite disposal

\begin{tabular}{|c|c|c|c|c|}
\hline $\begin{array}{c}\text { Background/origin of } \\
\text { the requirements }\end{array}$ & $\begin{array}{l}\text { Nature of the } \\
\text { requirements }\end{array}$ & $\begin{array}{c}\text { Addressee of the } \\
\text { requirements }\end{array}$ & Required solution & Deadline \\
\hline $\begin{array}{l}\text { Decrease of expenses } \\
\text { International RW } \\
\text { disposal approaches. } \\
\text { Decommissioning of } \\
\text { RBMK power units } \\
\text { and certain produc- } \\
\text { tion reactors }\end{array}$ & $\begin{array}{l}\text { Rejection of } \\
\text { deep disposal }\end{array}$ & $\begin{array}{l}\text { FSUE NO RAO's } \\
\text { investment } \\
\text { program }\end{array}$ & $\begin{array}{l}\text { 1. Adjustment of criteria set for } \\
\text { retrievable RW classification } \\
\text { 2. Establishment of siting } \\
\text { requirements } \\
\text { 3. Arranging for a siting process } \\
\text { to find a suitable site for reac- } \\
\text { tor graphite disposal in clay } \\
\text { formations and development of } \\
\text { relevant designs }\end{array}$ & $\begin{array}{l}\text { 1. } 2020 \\
\text { 2. } 2021-2022 \\
\text { 3. } 2023-2030 \\
\text { Established based on the count down from } \\
\text { the start of RBMK reactor core dismantling } \\
\text { A purpose-designed near-surface disposal } \\
\text { facility should become available by this } \\
\text { time with relevant operational experience } \\
\text { gained (AMB graphite disposed of) }\end{array}$ \\
\hline
\end{tabular}

Reactor graphite (Table 3). About 60 thousand tons of reactor graphite has been accumulated in operating and shutdown reactor plants in Russia. Most part of this amount shall be removed from the reactor units and disposed of. Under current standards, most part of reactor graphite is categorized as RW class 2 requiring extremely costly disposal option to be implemented. The main reason for this is the ${ }^{14} \mathrm{C}$ concentration in graphite exceeding the limit set for RW class 3 . The associated disposal cost is well understood by everyone, which has prompted research on graphite deactivation technologies that can be boiled down to a common transfer of ${ }^{14} \mathrm{C}$ from one form (well-fixed in the crystal lattice) to another (emissions or radiocarbon on filters). [16] presents an in-depth study on this issue with the main conclusion suggesting that it seems not feasible to consider graphite waste decontamination option, since graphite is deemed to be a good matrix providing ${ }^{14} \mathrm{C}$ retention.

If no decision is made, extremely high costs associated with any option whether its deep disposal of reactor graphite, its intermediate storage or continued maintenance of graphite RBMK reactor stacks seem to be inevitable.

LRW disposal (Table 4). Following the ratification of the Joint Convention, the LRW disposal technology implemented only in Russia suggesting RW injection into underground reservoir beds got recognition at an international level. Attempts made to prove the relevance of this technology to the so-called best practices promoted by the IAEA did not succeed. The IAEA pear review mission recognized the operational safety of the technology, nevertheless issuing a large number of comments regarding the long-term safety demonstration aspects. Relevant program is being currently implemented [17].

Another thing to note today is that in addition to discussions held at relevant Joint Convention meetings, there is an example of linking the termination of injection with the conclusion of large international contracts. At SCC, for example, a complex for RW immobilization is being constructed to ensure the conclusion of such a contract. But in general, operating organizations, including MCC and RIIAR, did not fully realize the graveness of the requirements on LRW disposal facility closure in the context of international activities and export of technologies, in particular, NPP construction abroad and reprocessing of foreign spent nuclear fuel. The only internationally accepted argument in favor of the continued operation of the injection facilities is the disposal of LRW from the decommissioning of legacy facilities, including the removal of LRW from near-surface LRW storage ponds at SCC and MCC.

Very low-level waste disposal (table 5). NPC development should be accompanied by relevant efforts on the demolition of no longer operated structures and building at nuclear legacy sites. Due to more and more intensive decommissioning activities, including the decommissioning of large facilities, the task of establishing low- and very low-level waste disposal system becomes more urgent. Even given the today's amounts of VLLW generation, real actions are required. For example, according to the annual report of 2018, Russian NPPs generated over 5.1 thousand $\mathrm{m}^{3}$ of VLLW SRW during that year accounting for over $80 \%$ of all SRW. Until recently,

Table 4. Main characteristics of the challenges associated with LRW disposal

\begin{tabular}{|c|c|c|c|c|}
\hline $\begin{array}{l}\text { Background/origin } \\
\text { of the requirements }\end{array}$ & Nature of the requirements & $\begin{array}{l}\text { Addressee of the } \\
\text { requirements }\end{array}$ & Required solution & Deadline \\
\hline $\begin{array}{l}\text { JC, } 190-\mathrm{FZ}, \text { IAEA } \\
\text { pear review mis- } \\
\text { sion }\end{array}$ & $\begin{array}{l}\text { Rejection of LRW disposal } \\
\text { practice and advance prepa- } \\
\text { ration aimed at ensuring the } \\
\text { long-term safety }\end{array}$ & $\begin{array}{l}\text { Three operating orga- } \\
\text { nizations applying this } \\
\text { technology and FSUE } \\
\text { NO RAO }\end{array}$ & $\begin{array}{l}\text { 1. Order on the development of tech- } \\
\text { nologies excluding LRW disposal, their } \\
\text { commissioning timeline and elabora- } \\
\text { tion of LRW DDF closure issues }\end{array}$ & $\begin{array}{l}\text { 1. } 2021 \text { (seventh } \\
\text { review meeting) } \\
\text { 2. } 2024 \text { (eighth } \\
\text { review meeting) }\end{array}$ \\
\hline
\end{tabular}


Table 5. Main characteristics of the challenges associated with VLLW

\begin{tabular}{|l|l|l|l|}
\hline $\begin{array}{l}\text { Background/origin } \\
\text { of the requirements }\end{array}$ & Nature of the requirements & Addressee of the requirements & \multicolumn{1}{|c|}{ Required solution } \\
\hline $\begin{array}{l}\text { Disposal effec- } \\
\text { tiveness }\end{array}$ & $\begin{array}{l}\text { Rejection of joint disposal } \\
\text { option for RW class 3,4 and } \\
\text { VLLW }\end{array}$ & $\begin{array}{l}\text { FSUE NO RAO and operating } \\
\text { organizations that can gain the } \\
\text { right for the disposal of such RW }\end{array}$ & $\begin{array}{l}\text { Industry-wide program on the } \\
\text { development of disposal facili- } \\
\text { ties for VLLW }\end{array}$ \\
\hline
\end{tabular}

the Federal State Unitary Enterprise NO RAO has developed no action plan in this area. Moreover, today RW classes 3 and 4 disposal facilities are being designed as one single structure inevitably resulting in significant costs. Obviously, under this state of affairs, certain problems were prompted by classification criteria suggesting that VLLW were not allocated into a separate class. Perhaps these issues will be addressed in the coming years, including by means of obtaining rights on such facilities construction by individual operating organizations. But, in essence, this is a big industry-wide problem and the best way to address it, is to solve it jointly with the one associated with the disposal of industrial waste with an increased radionuclide content.

RW disposal packages. The current situation suggesting massive use of extremely expensive containers, such as NZK, should be considered more than unsatisfactory. It's worth to note that the tariff is set per unit volume of RW packaging transferred for disposal, and all packages used today are non-returnable ones providing for an additional load both in terms of cost and the paid volume. For NZK container, for example, this figure amounts to $1 / 3$ of the volume (Fig. 2). A part of it provides adequate strength of the construction and limits the dose rate during waste transportation and handling operations, although this can be achieved by another mean. Thus, the operating organization pays thrice for this large and unnecessary part of the structure. Firstly, under the disposal tariff, the cost is payed for disposal, but the disposal capacity is not used. Secondly, it pays for the extra "metal" and "concrete" that the operator does not use. Thirdly, it pays for the transportation of additional

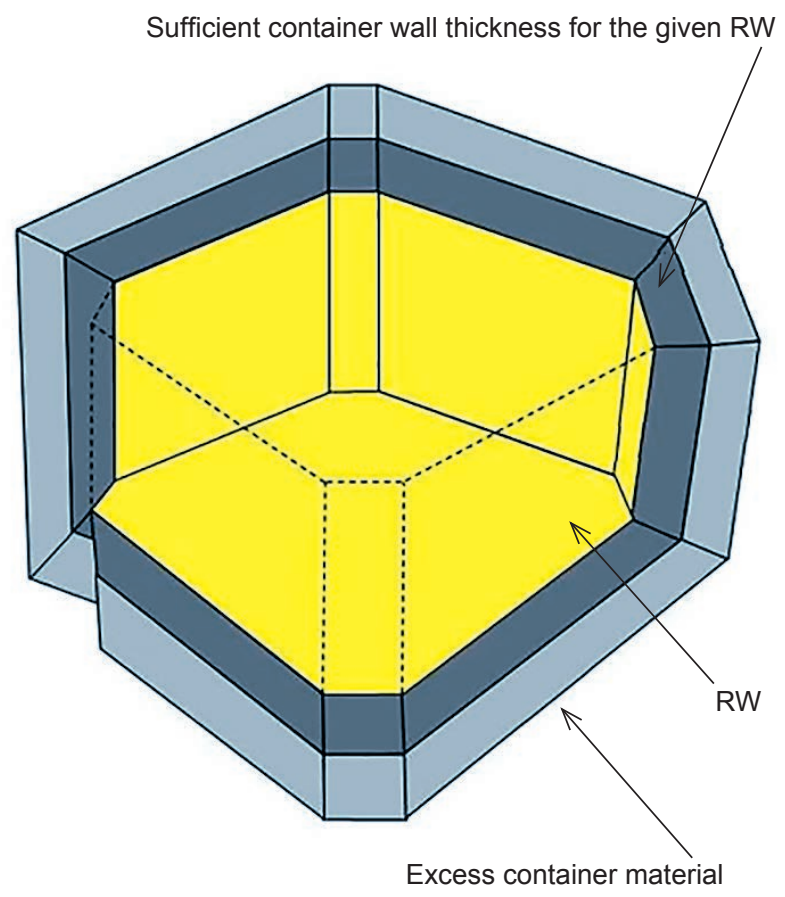

Figure 2. Use of container material

weight. As a result, the cost paid for waste disposal can exceed reasonable values by several or even tens of times. The issues associated with the fact that often low activity level RW are transferred for disposal are highlighted in $[18,19]$, which gives rise to a hope that certain additional requirements for contractors will be set forth in the future.

On the whole, the current situation discussed above seems to be quite complicated (Table 6) due to the lack of an interested and consolidated customer for the development of modern and efficient packaging solutions and the adjustment of

Table 6. Key USS RW price parameters

\begin{tabular}{|c|c|c|c|c|}
\hline Class & Tariff, thousand rub/ $\mathrm{M}^{3}$ & Disposal facilities' status & Applied containers & Container price, thousand rub per piece \\
\hline 1 & 1,424 & \multirow{2}{*}{$\begin{array}{l}\text { Design development, } \\
\text { URL construction }\end{array}$} & To be confirmed & \multirow[t]{2}{*}{ Not defined } \\
\hline 2 & 662 & & & \\
\hline 3 & 152 & $\begin{array}{l}\text { Design development, } \\
\text { construction and operation } \\
\text { of DF for RW class } 3 \text { and } 4\end{array}$ & $\begin{array}{l}\text { NZK-150-1.5P (V) } \\
\text { NZK -150-1.5P } \\
\text { AT28/29/30 } \\
\text { NZK - Radon }\end{array}$ & $80-110$ \\
\hline $\begin{array}{c}4 \\
4 \text { (VLLW) }\end{array}$ & 46 & No activities performed & $\begin{array}{l}\text { KRAD-1,36 } \\
\text { KRAD-3,0 } \\
\text { MK-1,36A }\end{array}$ & $80-100$ \\
\hline
\end{tabular}


the regulatory framework, if necessary. There are many areas for such upgrading and development, the only requirement in terms of standardization is the weight and size characteristics and units for loading and unloading operations. Some of the proposed solutions involve the use of flexible packaging [20], thin-walled metal containers, revolving protective covers, and, finally, containers manufactured from contaminated metal [21].

It seems quite possible that certain efforts are underway to workout some solutions in this area, including some comprehensive research. But in this case, the scientific and engineering community should be informed about these. Until now, no publication on this subject have been issued nether in the specialized scientific and technical Journal "Radioactive waste" nor in any other periodicals. Concluding on the topic of RW disposal packages, one should note once again that this is not the responsibility of the national operator, but the direct one of operating organizations generating the waste. And it is precisely through the development of a comprehensive plan, agreed upon with the national operator, that this challenge is to be resolved. No particular deadlines have been set up, but each year the use of ineffective packaging will result in additional costs of tens and hundreds of millions of rubles.

Other aspects. In the past, we already experienced some cases when initiatives associated with increasing the efficiency came up against the limitations set up for the final stages of nuclear life cycle. Thus, an increase in the burnup of nuclear fuel has encountered restrictions associated with its transportation and reprocessing. At present, a similar situation may arise with the so-called tolerant fuel. Its introduction into the open fuel cycle does not contradict anything, however, in the case of focusing on closed NFCs, the cost of relevant reprocessing technologies will obviously grow. So far, this flip side of the coin has not been discussed in the scientific literature.

One cannot but mention the construction of nuclear power plants abroad. Until recently, to a large extent the success of Russian offers for the construction of power units was associated with the construction cost. Obviously, over time this will turn into the cost of power generation with the RW generation factor playing a significant role in it. Obviously, this process is not fast, but inevitable. Therefore, concerns regarding the decrease in RW generation, increasing the efficiency of waste processing and, accordingly, reducing the cost of waste disposal will become increasingly relevant.

Prospects until the end of the century. We have already noted the positive role of the strategic document [1]. At the same time, two comments are to be expressed on the Strategy, namely, referring to RW management challenges. The first one concerns the open NFC. Provisions of the Strategy state that: "By 2100, under the open nuclear fuel cycle (reactors with a thermal neutron spectrum not using MOX / REMIX fuel), the volume of spent nuclear fuel stored in SNF storage facilities will require a significant expansion of the existing infrastructure, and also does not correspond to the concept of the approved State SNF and RW Management Policy" $[1$, p. 20]. The first part of this statement seems to be totally correct. The second part refers to a non-existent document, since the "State Policy Fundamentals in the Field of Nuclear and Radiation Safety" (hereinafter referred to as the Fundamentals) approved by the President of Russia clearly states the focus on increasing the capacity of SNF reprocessing and disposal facilities until 2030. Moreover, the Fundamentals stipulate that the effectiveness of measures on the implementation of the State Policy shall be evaluated, in particular, based on the following indicators: a) the ratio of reprocessed spent nuclear fuel and its total volume; b) the amount (volume) and activity of non-retrievable radioactive waste disposed of in so called conservation facilities for non-retrievable radioactive waste and (or) RW disposal facilities; c) the ratio between the volume of conditioned and disposed RW at disposal sites and the total amount of accumulated and generated retrievable RW (Section $\mathrm{V}$ of the Fundamentals).

The second comment is related to an attempt to break away from RW disposal as a problem that does not have a solution from the traditional, for most countries, perspective - option of direct SNF disposal and existing SNF reprocessing technologies. A section of the Strategy states that: "The safety of RW disposal supposed to be ensured for hundreds of thousands and millions of years raises quite reasonable doubts about the reliability of such long-term forecasts. Burning and transmutation of the longest-lived isotopes in fast-neutron power reactors or in purpose-designed critical / subcritical reactors located at centralized SNF reprocessing plants provides convincing evidence on the safety of radioactive waste management". Quite similarly, it is formulated in the concept of a molten salt reactor burning the minor actinides, which call into question the further development of nuclear power [22].

In our opinion, in these statements the focuses seem to be placed wrong. Over 50 years long timeline of nuclear power evolution many options describing its further development have been implemented all around the globe: sustainable development (China, India); development and slow 
shutdown (France); development and decisive shutdown (Germany); development and stagnation (USA); complete failure and restart (Armenia); sustainable development and large-scale shutdown after a disaster (Japan). However, the statements concerning the particular hazard of minor actinides were not decisive in any of the decisions regarding the scenarios to be followed. The challenge of SNF and RW management had its own negative subtext, but it was considered as completely secondary in comparison with the negative perception of severe accidents and the consequences of nuclear defense activities. Thus, unaddressed challenges of the past and present, including the underdevelopment or incompleteness of the disposal system in the vast majority of countries is seen as the main reason for that. Therefore, it seems completely impractical or even dangerous to consider the opportunities for addressing the challenges under the future technologies perspective, while casting doubt on the globally developed system of safety requirements on SNF and RW disposal. On the contrary, it should be demonstrated with confidence that the challenges of the past and the present can be resolved, and only on this basis even more impeccable technologies can be proposed, which, perhaps, could be considered somewhat detrimental for the economy supposing the current tools used for the assessment of relevant environmental aspects. An authoritative analysis [23] declares the lack of economic advantages from the use of technologies providing for the burnup of long-lived trans-uranium elements. However, such statements can also be adjusted due to today's underestimation of relevant environmental aspects. On the other hand, the conclusion from another authoritative analysis [24] seems to be totally true with two quotes from it requiring particular attention. The first one refers to the role of investments in terms of required efforts on the geological disposal of already accumulated RW inventory, including investments into new reactor technologies. The comment provided by the Commission could be summarized as follows: "In other words, we do not believe that today's reprocessing technologies or technological developments of 3-4 decades will affect the need for an integrated strategy on disposal facility's (facilities') siting and licensing”. This seems to be especially true for defense HLW and some forms of federally owned spent nuclear fuel, which can and should be regarded as top-priority ones for direct disposal in a suitable facility. The second quote also matches with our position: "Our conclusion regarding the need for geological disposal capacities were not based on the position regarding the introduction of a closed NFC in the US".
It should be noted that this conclusion seems to be also valid for Russia, since we have a large amount of accumulated waste, and the differences between the current national policies of Russia and the US on the discussed issue are not that much critical. As it comes to the development of reactor technologies: the US recognizes the possibility of scientific and engineering breakthroughs in the field of nuclear technologies, including the Westinghouse's application for the state funding of the lead coolant reactor project; Russia sees its priority in the development of fast reactor technologies and implementation of the state program for new reactor technologies, including the BREST-300 reactor installation. As for RW disposal, including the geological one, a system of landfills is being operated in the US with the deep disposal Yucca Mountain project being suspended. A system of near-surface RW disposal facilities is currently being developed in the Russian Federation with the start of relevant efforts on URL and DDF RW development.

To conclude the overview of international experience in this field, one should note that coordination of long-term strategies for the development of nuclear and RW disposal technologies addressing a long-term perspective will be required in the future, but the establishment of a disposal system for already accumulated RW, including the geological DDFs should be considered as an urgent need. This need is supported at the government level and is recognized by most experts both in Russia and around the globe.

It is important to determine the time frame during which a detailed study on establishing relationships between the development of new power technologies and the corresponding transformation of USS RW disposal system should be started. Probably, the experience gained from the operation of BREST OD-300 reactor unit will help to specify this timeframe, i.e. after 2030. Advances in the development of nuclear technologies will be viewed as a sign calling for more focus to be placed on the transformation of waste management systems involving the entire arsenal of strategic planning tools. At the same time, already accumulated RW, the existing and constructed fleet of reactor facilities and nuclear technologies predetermine the need for the establishment of full-fledged disposal systems covering all RW types and its operation over many decades.

Tools for the implementation of the proposals. Practice has shown that strategic planning methods can be considered as most adequate ones. Moreover, thorough examination of relevant engineering solutions appears to be a distinctive feature of their application within the framework of the proposals 


\section{Table 7. Key issues for the harmonization of the USS RW and NPC industrial activities}

\begin{tabular}{|c|c|c|c|c|}
\hline № & Focus area & International experience & $\begin{array}{l}\text { Best practices were first } \\
\text { implemented (year) }\end{array}$ & $\begin{array}{l}\text { Financial losses if no justified decision is made, } \\
\text { RUB }\end{array}$ \\
\hline 1 & $\begin{array}{l}\text { Vitrified RW from SNF } \\
\text { reprocessing }\end{array}$ & Available & 2020 & $\begin{array}{l}\text { Over } 1 \text { bln RUB (construction of additional } \\
\text { storage facility and storage for up to } 50 \text { years) }\end{array}$ \\
\hline 2 & Reactor graphite & $\begin{array}{l}\text { Siting efforts, } \\
\text { shallow DF concepts }\end{array}$ & $2020-2025$ & Over 1 bln RUB per RBMK unit \\
\hline 3 & LRW disposal & Not available & $2021-2024$ & Loss of export contracts \\
\hline 4 & VLLW & Available & $2020-2025$ & $\begin{array}{l}\text { No less than } 0.3 \text { bln per year if disposed } \\
\text { of in DF designed for RW class } 3 \text { and } 4\end{array}$ \\
\hline 5 & $\begin{array}{l}\text { New packages for disposal, } \\
\text { including those fabricated } \\
\text { from contaminated metal }\end{array}$ & Available & $2025-2030$ & $\begin{array}{l}\text { Several billions (fine cleaning } \\
\text { or disposal of metal RW as RW) }\end{array}$ \\
\hline
\end{tabular}

expressed. None of the provisions should be adopted without detailed feasibility study. Another feature is the focused placed not on the content of binding and normative documents, but on the assessments of safety and the associated costs. This proposal is based on an optimistic outlook on future binding and regulatory documents. In other words, the development of strategic plans should include both necessary scientific high-quality support and the necessary and meaningful engagement of operating organizations.

\section{Conclusions}

Five focus areas associated with different timeframes for making key decisions have been identified as the main processes and tasks requiring close cooperation between the organizations of the FSLC complex and operating organizations of the industry (Table 7).

Each of the cases examined suggests not only potential savings amounting to billions of rubles, but also determines the environmental profile of the industry and demonstrates the adherence to efficient planning and liability to future generations.

Basically, some tools are available enabling to work out the decisions on the issues being considered critical for the industry, including those associated with long-term perspective, as well as significant experience in strategic planning.

RW classification for disposal purposes is considered as a pivotal issue with certain disadvantages of the existing system that seems to be too obvious and discussed for too long, often without a clear stance of the stakeholders.

\section{References}

1. Strategiya razvitiya yadernoj energetiki Rossii do 2050 goda i perspektivy na period do 2100 goda [Strategy for nuclear power development in Russia until
2100] Approved by the order of Scientific Technical Council's Presidium of the State Corporation Rosatom on the 26th of December, 2018. Moscow, 62 p.

2. Problemy yadernogo naslediya i puti ih resheniya. [Nuclear legacy challenges and their solutions]. Vol. 1. Under general edt. of E. V. Evstratov, A. M. Agapov, N. P. Laverov, L. A. Bolshov, I. I. Linge. Moscow, JSC Energopromanalitika Publ., 2012, $356 \mathrm{p}$.

3. Kommentarij k Federalnomu zakonu "Ob obrashchenii s radioaktivnymi othodami i o vnesenii izmenenij $\mathrm{v}$ otdelnye zakonodatelnye akty Rossijskoj Federacii”. [Explanatory note on the Federal Law On Radioactive Waste Management and Some Amendments Introduced to Particular Legal Acts of the Russian Federation]. 2nd edition, supplemented. Edt. By T. L. Elfimova. Moscow: Central Office of the State Duma, 2014, 208p.

4. Bolshov L. A., Linge I. I., Utkin S. S. et al. Stanovlenie nacionalnoj sistemy obrashcheniya s radioaktivnymi othodami: uroki, uspekhi, ozhidaniya [Establishment of the national radioactive waste management system: lessons learned, highlights and expectations]. Atomnaya energiya Atomic Energy, 2011, vol. 111, issue 3, pp. 126-131. (In Russian).

5. Strategicheskie podhody $\mathrm{k}$ resheniyu ekologicheskih problem, svyazannyh s vyvedennymi iz ekspluatacii obektami atomnogo flota na SeveroZapade Rossii [Strategic approaches to addressing environmental issues associated with decommissioning of nuclear naval facilities in the North-West of Russia] S. V. Antipov, R. V. Aratyunyan, L. A Bolshov et al.; under general edt. of A. A. Sarkisov; Nuclear Safety Institute of RAS. Moscow, Science Publ., 2010. 346 p.: fig. - ISBN 978-5-02-037489-8. (In Russian).

6. Strategicheskij master-plan resheniya problem Techenskogo kaskada vodoemov FGUP «PO «Mayak» [Strategic Master Plan Addressing the Challenges of the Techa Cascade of Water Reservoirs at PA Mayak 
site]. Nuclear Safety Institute RAS et al. - Approved by the Director General of the State Corporation Rosatom on February 12, 2016. (In Russian).

7. Strategiya sozdaniya punkta glubinnogo zahoroneniya radioaktivnyh othodov [Strategy for the development of a deep disposal facility for radioactive waste] Radioaktivnye othody - Radioactive Waste, 2018, no. 2 (3), pp. 114-120. (In Russian).

8. Dorofeev A. N., Bolshov L. A., Linge I. I., Utkin S. S., Savelyeva E. A. Strategicheskij master-plan issledovanij $\mathrm{V}$ obosnovanie bezopasnosti sooruzheniya, ekspluatacii i zakrytiya punkta glubinnogo zahoroneniya radioaktivnyh othodov [Strategic Master Plan for Research Demonstrating the Safety of Construction, Operation and Closure of Radioactive Waste Deep Disposal Facility]. Radioaktivnye othody - Radioactive Waste, 2017, no.1, p. 32-41. (In Russian).

9. Abramov A. A., Dorofeev A. N. Sovremennoe sostoyanie i perspektivy razvitiya sistemy obrashcheniya s RAO v Rossijskoj Federacii [Radioactive Waste Management System in the Russian Federation: State-of-Art and Perspectives for Development]. $R a$ dioaktivnye othody - Radioactive Waste, 2017, no. 1, p. 10-21. (In Russian).

10. Dorofeev A. N., Linge I. I., Samoylov A. A., Sharafutdinov R. B. K voprosu finansovo-ekonomicheskogo obosnovaniya povysheniya effektivnosti normativnoj bazy EGS RAO [Enhancing the efficiency of USS RW regulatory framework: financial and economic feasibility study]. Radioaktivnye othody - Radioactive Waste, 2017, no.1, p. 22-31. (In Russian).

11. Decision of Section № 1 "Environmental and radiation safety of RW long-term storage, conservation and disposal facilities” STC № 10 “Ecology and radiation safety" of the State Corporation Rosatom of April 12, 2019 "On demonstrating the long-term safety of near-surface disposal facilities for SRW Class 3 and 4". (In Russian).

12. Kachan P. P, Krasnov I. M., Stakhiv M. R. Opyt ekspluatacii kompleksa pererabotki radioaktivnyh othodov na Smolenskoj AES [RW Processing complex at Smolensk NPP: Operational Experience]. Radioaktivnye othody - Radioactive Waste, 2018, no.1(2), p. 34-41. (In Russian).

13. Avezniyazov S. R., Stakhiv M. R. Opyt raboty po obrashcheniyu s ZHRO na Kol'skoj AES [Managing LRW at Kola NPP] Radioaktivnye othody - Radioactive Waste, 2018, no. 4 (5), p. 49-54 (In Russian).

14. Blokhin P. A., Dorofeev A. N., Linge I. I., Merkulov I. A., Seelev I. N., Tikhomirov D. V., Utkin S. S., Khaperskaya A.V. O vozmozhnostyah upravleniya harakteristikami borosilikatnogo stekla pri pererabotke OYAT VVER-1000 na ODC "GHK" [On the potential of controlling borosilicate glass characteristics during SNF WWER-1000 reprocessing at PDC MCC] Radioaktivnye othody - Radioactive Waste, 2019, no. 2 (7), p. 49-57. (In Russian). DOI: 10.25283/2587-9707-2019-2-49-57

15. Kashcheev V. A., Shchadrin A. Yu. Obrashchenie s RAO ot pererabotki smeshannogo nitridnogo uranplutonievogo OYAT [Managing RW from reprocessing of mixed nitride uranium plutonium SNF]. Proceedings of the IX Russian Conference Radiochemistry 2018, St.-Petersburg. 2018, 394 p. (In Russian).

16. Dorofeev A. N., Komarov E. A., Zaharova E. V., Volkova A. G., Linge I. I., Ivanov A. Yu., Utkin S. S., Pavlyuk A. O., Kotlyarovskyi S. G. K voprosu zahoroneniya reaktornogo grafita [On reactor graphite disposal]. Radioaktivnye othody - Radioactive Waste, 2019, no. 2 (7), p. 18-30. (In Russian). DOI: 10.25283/2587-9707-2019-2-18-30

17. Dorofeev A. N., Savelyeva E. A., Utkin S. S., Ponizov A. V., Sharafutdinov R. B., Kudryavtsev E. G., Pron I. A., Konovalov V. Yu. Evolyuciya obosnovaniya dolgovremennoj bezopasnosti PGZ ZHRO [Evolution of the long-term safety case for LRW disposal facility]. Radioaktivnye othody - Radioactive Waste, 2017, no. 1, p. 55-64. (In Russian).

18. Abramov A. A., Dorofeev A. N., Deryabin S. A. Razvitie EGS RAO v ramkah rabot o Federal'noj celevoj programme obespecheniya yadernoj i radiacionnoj bezopasnosti [USS RW development under the Fedral Targeted Program Nuclear and Radiation Safety]. Radioaktivnye othody - Radioactive Waste, 2019, no. 1 (6), p. 8-24. (In Russian).

19. Pron I. A., Konovalov V. Yu. Opyt ekspluatacii pripoverhnostnogo punkta zahoroneniya radioaktivnyh othodov 3 i 4 klassov [Near-surface disposal facility for radioactive waste class 3 and 4: operational experience]. Radioaktivnye othody - Radioactive Waste, 2018, no. 4 (5), p. 8-14. (In Russian).

20. Radchenko M. V., Kormilitsyna L. A., Matyunin Yu. I., Mogulyan V. G. Mnogocelevye upakovki dlya radioaktivnyh othodov [Multipurpose packages for radioactive waste]. Radioaktivnye othody - Radioactive Waste, 2017, no.1, p. 74-84. (In Russian).

21. Blokhin P. A., Vaneev Y. E., Panchenko S. V. Ocenka vozmozhnosti povtornogo ispol'zovaniya metallicheskih radioaktivnyh othodov $\mathrm{v}$ atomnoj promyshlennosti [Evaluation of the Possibility of Recycling Metal Radwastes in the Nuclear Industry]. Atomnaya energiya - Atomic Energy, 2014, no.117 (2), pp. 100-105. (In Russian).

22. Ponomarev L. I., Belonogov M. N. Bystryj zhidkosolevoj reaktor na osnove evtektiki LiF-NaF-KF kak szhigatel Np, Am, Cm [Fast molten salt reactor based on LiF-NaF-KF eutectic considered as Np, Am, Cm incinerator] Atomnaya energiya - Atomic Energy, 2019, vol. 126, no. 3, p. 123-135. (In Russian). 
23. The Future of the Nuclear Fuel Cycle. An Interdisciplinary MIT Study. - Massachusetts Institute of Technology, 2011. -237 p.
24. Blue Ribbon Commission on America's Nuclear Future. Report to the Secretary of Energy. January 2012. $-158 \mathrm{p}$.

\section{Information about the authors}

Bolshov Leonid Aleksandrovich, Member of the Russian Academy of Sciences, Professor, Doctor of Physical and Mathematical Sciences, Head of Research, Nuclear Safety Institute Nuclear Safety Institute of RAS (52, Bolshaya Tulskaya St., Moscow, 115191), e-mail: bolshov@ibrae.ac.ru.

Linge Igor Innokentevich, Doctor of Technical Sciences, Deputy Director, Nuclear Safety Institute of RAS (52, Bolshaya Tulskaya St., Moscow, 115191), e-mail: linge@ibrae.ac.ru.

\section{Bibliographic description}

Bolshov L. A., Linge I. I. Building Consistency between Development Stages of Nuclear Power Complex and RW Management System. Radioactive Waste, 2019, no. 3 (8), pp. 14-27. DOI: 10.25283/2587-97072019-3-14-27. (In Russian). 